\title{
Impact of Brand Value on Financial Performance of Banks: An Empirical Study on Indian Banks
}

\author{
Sangeeta Arora, Neha Chaudhary* \\ Department of Commerce and Management, Guru Nanak Dev University, India
}

Copyright $(\mathcal{C} 2016$ by authors, all rights reserved. Authors agree that this article remains permanently open access under the terms of the Creative Commons Attribution License 4.0 International License.

\begin{abstract}
Purpose: The biggest challenge for the banking industry is to tangibilize the intangible banking experience. One way of overcoming this challenge is creation of strong brands. It has been well recognized that Brands are regarded as most important corporate asset but recently serious attempts have been made by various organizations in order to estimate their brand value (Farquhar, 1989). Academic literature has revealed that high brand value resulted in increased financial returns and shareholder value, which leads to superior financial performance. This research focuses on the investigating the impact of brand value on various financial indicators on of banks. Design/ Methodology/Approach: The investigation is designed as a quantitative study and is based on the brand value of Indian banks. The sampling frame constituted Top 10 banks listed by Brand Finance, a leading brand valuation agency. Five banks were selected on the basis of highest brand values reported in Brand Finance Banking 500, (2014) from Public sector as well as Private sector banks. In public sector banks, State Bank of India, Punjab national bank, Bank of Baroda, Bank of India and Canara bank were selected. Amongst private sector banks, ICICI, HDFC, Axis, Kotak Mahindra and Yes bank form the sample of the study. The data of Brand values were collected from the report of Brand Finance Banking 500 published during 2009-2014. Multiple Regression analysis has been applied in order to analyze the impact of Brand value on various financial indicators such as Return on Assets (ROA), Return on equity (ROE), Return on Investments (ROI), Stock Prices and Earnings Per share (EPS). Findings: The findings revealed that Brand value has significant impact on the financial performance of banks. Brand value has significant negative impact on ROA, ROI and ROE. This negative phenomenon indicates the marginal diminishing returns of the bank's brand advantage, ceteris paribus (Tsai and Chang, 2012) whereas brand value has significant positive impact on Stock Prices and EPS. Originality/Value: This is the most comprehensive quantitative study in the field of branding and financial performance of the banking sector. There has been limited research on the impact of brand value on the financial
\end{abstract}

performance of banks. This study provides new insights for marketing managers and brand valuation agencies.

Keywords Brand Value, Return on Assets, Return on Equity, Return on Investments, Stock Prices and Earnings per Share

\section{Introduction}

The biggest challenge for the banking industry is to tangibilize the intangible banking experience. One way of overcoming this challenge is creation of strong brands. It has been well recognized that brands are regarded as one of the most important corporate asset but it is only recently serious attempts have been made by various organizations in order to estimate their brand value (Farquhar, 1989). Academic literature has revealed that high brand value results in increased financial returns, shareholder value, profitability etc. which leads to superior financial performance. Hence, it is presumed that Brand equity has recorded a significant impact on performance of banks. In this context, by using the regression analysis, the objective of the research is to stress out the impact of brand value on financial performance of selected commercial banks from 2007-2014.

This chapter deals with assessing the impact of brand value on the financial performance of banks. Although numerous studies have found a significant relationship between brand value and financial performance (Doyle,2001; Madden et al., 2002; Verbeeten \& Vijin, 2006; Angulo 2007; Madikizela 2007; Kim et al. 2008; Ohnemus 2008; Rego 2009; Stahl, 2011; Rasti, 2013 but only a few studies have analyzed this relationship in service sector particularly in the banking sector (Madikizela,2007;Ohnem us,2009). Banking sector plays a very crucial role in financing the real economy and ensuring the financial stability.

Brand valuation is necessary as it puts significant impact on the firm's profitability. It is argued that brand is central to firm's ability to earn super profits and exerts an influence on 
the resources and capabilities that are directly responsible for a firm's success. No other intangible has the same linear link between the market which is the source of a company's revenues, and the wealth the company creates for its shareholders (Sinclair, 2009).

The need for brand valuation arose in 1980s when the wave of brand acquisitions resulted in large amount of goodwill. There was no accounting criterion to deal with the increased value of intangible assets. As a result, companies were penalized for such value enhancing acquisitions. They either had to write off the amount to reserves or to suffer huge amortization charges which resulted in lower asset base than before the acquisition. Countries like UK, France, Australia and New Zealand recognized the value of acquired brands as intangible assets and reflected these on the balance sheet of the acquiring company. In the mid-1980s, Reckitt \& Colman, a UK-based company, placed a value on its balance sheet for the Airwick brand that it had recently bought. Grand Metropolitan did the same with the Smirnoff brand. Therefore brand valuation has gained importance from 1980 onwards .As of now Brand valuation is required under IFRS 3 (International Financial Reporting Standards). It demands that brands and other intangible assets are valued by a company independent of the business and auditors. The above discussion shows that the foreign companies took deeper interest in branding and Branding is gaining importance in India as well.

\section{Brand Valuation in India}

The introduction of IFRS represents a major shift in the way that companies undertake their financial reporting .IFRS 3 requires identifiable assets to be recognized on the balance sheet of the acquiring entity. Brands are one type of intangible asset, which are frequently claimed to have indefinite useful economic lives. Where acquired brands are recognized on the balance sheet post-acquisition it is important to establish a robust and supportable valuation model using best practice valuation techniques that can be consistently applied at each annual impairment review. Therefore, several brand consulting agencies are calculating the brand values of most preferred brands (Interbrand, Brand finance, Brandz, Intangible business etc.) by adopting different methodologies. The current study takes into consideration the methodology adopted by Brand Finance 2015. Brand Finance was set up in 1996 with the aim of 'bridging the gap between marketing and finance'. Brand Finance is the world's leading independent brand valuation and strategy consultancy. Brand finance facilitates companies to connect their brands to the bottom line, building robust business cases for brand decisions, strategies and investments and to evaluate marketing programmes. The Brand Finance Banking 500 is an annual ranking of the most valuable brands in banking. It is the only firm in the world to publish the values of the top 500 banking brands.

\section{The Main Reasons behind Selecting Brand Finance}

\subsection{Independence}

Brand Finance is impartial and independent because they have no vested interest in particular outcomes of a project and recommendations are entirely independent. It works collaboratively with many other agencies and consultancies.

\subsection{Technical Credibility}

Brand Finance has high technical standards. Their work is frequently peer reviewed by the big four audit practices and has been accepted by tax authorities and regulatory bodies around the world. It is one of the few companies certified to provide brand valuations that are fully compliant with ISO 10668, the global standard on monetary brand valuations.

\subsection{Transparency}

Brand Finance approach is to work openly, collaboratively and flexibly with clients and will always reveal the details of the modeling and analysis. This means clients always know what lies behind 'the number' that is given to a particular brand.

\subsection{Expertise}

Brand finance possesses a unique combination of skills and experience. It employs functional experts with marketing, research and finance.

\section{Explanation of Brand Valuation Methodology}

Brand Finance calculates the values of the brands by using the 'Royalty Relief approach'. This approach estimates the likely future sales that are attributable to a brand and calculating a royalty rate that would be charged for the use of the brand, i.e. what the owner would have to pay for the use of the brand - assuming it were not already owned.

The steps in this process are as follows:

Calculate brand strength on a scale of 0 to 100 based on a number of attributes such as emotional connection, international presence and sustainability. This score is known as the Brand Strength Index.

Determine the royalty rate range for the respective brand sectors. This is done by reviewing comparable licensing agreements sourced from Brand Finance's extensive database of license agreements and other online databases.

The brand strength score is applied to the royalty rate range to arrive at a royalty rate. For example, if the royalty rate range in a brand's sector is $1-5 \%$ and a brand has a brand strength score of 80 out of 100 , then an appropriate royalty 
rate for the use of this brand in the given sector will be $4.2 \%$.

Determine brand specific revenues estimating a proportion of parent company revenues attributable to a specific brand. Brand specific revenues are a function of historic revenues, equity analyst forecasts and economic growth rates.

Apply the royalty rate to the forecast revenues to derive brand revenues.

Brand revenues are discounted post tax to a net present value which equals the brand value.

Relief from Royalty is the preferred methodology of most valuation professionals. Therefore, in the current study, data of brand values are taken from the Brand finance banking report 2013.

\section{Data and Methodology}

The variables examined in this study are derived RBI official website, CMIE PROWESS and Brand Finance Reports (2007-2014) .The Time period for the study is 8 years from 2007 to 2014 Top 10 banks, 5 each in public sector banks as well as private sectors are selected for the study. These banks are selected on the basis of highest brand values reported in Brand Finance Report, 2013. All the accounting information is consolidated on 31 March of each year.

Majority of researchers have analyzed the financial performance by using Return On Assets, Return On Equity ,Return On Investments ,Earnings Per Share and Stock Prices (Simon \& Sullivan, 1993; Barth et al, 1998; Jacobson, 2001; Smith and Wright, 2004; Chu \& Keh, 2006; Verbeeten \& Vijin, 2006; Eng \& Keh, 2007; Angulo, 2008; Mirik \& Jacobson, 2008; Ohnemus, 2008; Mizik, 2009; Krasnikov et al., 2009; Ohnemus, 2010; Edmans, 2011; Kirk et al., 2012; Hsu et al, 2013; Tsai \& Chang, 2012; Nordeen, 2013; Gherghina et al, 2015). Therefore, these measures have incorporated as a proxy of Financial Performance in the study. The data of ROA, ROE and ROI, are retrieved from RBI official Website whereas EPS and Stock Prices are obtained from CMIE PROWESS. With regard to Brand Value, the data are compiled from Brand Finance reports (2007-2014).

\section{Hypotheses Development}

The link between brand value and financial performance has been hypothesized as positive, negative and neutral.

Return on assets: Return on Assets is the most widely used measure of financial performance. The ROA, defined as net income divided by total assets, reflects how well a bank's management is in using the bank's real investment resources to generate profits. The ratio of Return on Asset is one of the accounting standards which reveals the efficiency rating of the director in applying the existing sources to make profit and is one of the profit-making ratios used in the analysis of companies. Number of studies (Smith and Wright, 2004; Eng and Keh, 2007; Ohnemus, 2008; Mizik, 2009; Krasnikov et al., 2009; Gherghina et al, 2015) have examined the impact of brands on Return on Assets. They have found a positive impact of brands on ROA. This was based on the assumption that branding reduces inefficiencies caused by asymmetric information, thereby ultimately leading to transparency. Smith and Wright, 2004 investigated the relationship between brand elements and return on assets and found the positive influence of brand elements on return on assets. Eng \& Keh, 2007 found out that brand value estimates obtained from Inter brand and financial world magazine, are positively related to return on assets for three years. After three years ROA declined due to excessive expenditure on brand initiatives. Ohnemus \& Jenster, 2009 revealed that companies with balanced brand generate high return on assets. Unbalanced brand investments resulted in decline of Return on Assets. In order to analyze, whether these findings are consistent to the present study, the following hypothesis were developed:

Ho: 1 There is no significant impact of Brand value on financial performance measured with Return on Assets

$H_{1}: 1$ There is significant impact of Brand value on financial performance measured with Return on Assets

Return on equity: This is another important indicator of performance which tells us how the company has used the resources of its owners. In other words, it reveals how much profits a company has generated with the money of shareholders. This ratio reflects the extent to which the objective of wealth maximization of shareholders has been achieved. The amount of net income returned as a percentage of shareholders equity. Based on the previous literature, it is assumed that Return on Equity affects the brand value either positively or negatively. Aaker and Jacobson, 2001 revealed in their study that brand equity has significant positive influence on Return on Equity. Higher brand value leads to higher return on Equity. The findings of Ohnemus, 2010 reflected that high advertising spending leads to low return on equity. Media prominence and advertising increases the brand value of firms (Hynes, 2008), whereas decreases the return on equity (Ohnemus, 2010). Tsai \& Chang, 2012 found out that banks with brand advantage subsequently have a lower return on equity. This negative phenomenon indicates the marginal diminishing returns of the bank's brand advantage, ceteris paribus i.e. the brand advantage declines with the excessive branding efforts. In order to analyze, whether these findings are consistent to the present study, the following hypothesis were developed:

Ho: 2 There is no significant impact of Brand value on financial performance measured with Return on Equity

H1: 2 There is significant impact of Brand value on financial performance measured with Return on Equity

\section{Return on Investment}

ROI measures the amount of return on an investment 
relative to the investment's cost. Mixed evidences were found which investigate the impact of brand value on Return on Investments. Sinclair, 2003 claimed that Strong brands results in better investment performance. Angulo, 2008 found the positive link between brand value and financial performance measured with Return on Investments whereas Verbeeten \& Vijin, 2006 revealed that there is negative association between branding and Return on investment. Established brand equity leads to high return on investment (Nordeen, 2013). In order to analyze, whether these findings are consistent to the present study, the following hypothesis were developed:

Ho: 3 There is no significant impact of Brand value on financial performance measured with Return on Investments

H1: 3 There is significant impact of Brand value on financial performance measured with Return on Investments.

Stock Prices: A share price is the price of a single share of a number of saleable stocks of a company, derivative or other financial asset. In layman's terms, the stock price is the highest amount someone is willing to pay for the stock, or the lowest amount that it can be bought for. In the study, stock prices reflect the share price (closing price) of the respected banks. Previous studies provide strong evidence of the existence of the link between brand value and stock prices (Simon \& Sullivan, 1993; Barth et al, 1998; Jacobson, 2001; Chu \& Keh, 2006; Ohnemus \& Jenster, 2007; Mirik \& Jacobson, 2008; Edmans, 2011; Kirk et al., 2012; Hsu et al, 2013).The study presumed that brand value is the building block which helps in accelerating the share prices. Investors prefer to hold shares in well-known companies and Brand value act as a proxy for assessing the reputation and goodwill of the company (Eng \& Keh, 2007). Edmans, 2011 also asserted that higher brand value lead to more share prices. In order to analyze, whether these findings are consistent to the present study, the following hypothesis were developed:

Ho: 3 There is no significant impact of Brand value on financial performance measured with Stock Prices

H1: 3 There is significant impact of Brand value on financial performance measured with Stock Prices

EPS: Earnings per share are regarded as an important measure of financial performance. EPS is the monetary value of earnings per outstanding share of common stock for a company. Madikizela (2007); Angulo (2007); Mizik (2009); Gherghina et al (2015) have used EPS as performance measure. EPS is a popular indicator of shareholder return. These studies have reported the positive as well as negative impact of Brand value on EPS. The banking sector has potentially created a link between brand and shareholder return. In order to analyze, whether these findings are consistent to the present study, the following hypothesis were developed:

Ho: 4 There is no significant impact of Brand value on financial performance measured with Earnings per Share

H1: 4 There is significant impact of Brand value on financial performance measured with Earnings per Share
Age: The first control variable used in the study is age of the bank, which is calculated by the establishment dates of the selected banks. Chen (2001) stated that older firms may or may not be more profitable due to economies and diseconomies of scale. Age of the firm has been computed from the year of incorporation of the company till each year of the study. Gherghina et al (2015) reflected the positive influence of age on financial performance.

Size: Another control variable used in this research is company size, which is calculated by the logarithm of assets. Bank size accounts for the existence of economies or diseconomies of scale, Naceur \& Goaied (2008). The variable is measured as the natural log of total assets, Saona (2011). Economic theory suggests that market structure affects firm performance ,Haron (1996) and that if an industry is subject to economies of scale, larger institutions would be more efficient and could provide service at a lower cost (Rasiah, 2010a). Also, the theory of the banking firm asserts that a "firm enjoys economies of scale up to a certain level, beyond which diseconomies of scale set in. It implies that profitability increases with increase in size, and decreases as soon as there are diseconomies of scale. Thus, literature has shown that the relationship between the bank size and profitability can be positive or negative (Barth et al,1998; Staikouras \& Wood, 2004; Athanasoglou et al., 2005; Eng \& Keh (2007); Flamini et al., 2009; Dietrich \& Wanzenrid, 2009; Naceur \& Omran, 2011; Gherghina et al (2015)).

Ownership: Ownership is taken as another control variable which influence the financial performance of banks. In the study, 1 is given to public sector banks and 2 is given to private sector banks.

\section{Model Formulation}

The study used Regression model that allowed investigating the impact of brand value on financial performance of banks. The analyzed sample has 10 commercial banks which operate in India. As all the 10 banks from the sample are observed during 2007-2014, the study employed Time dummies.

The study has employed following models:

Is $t$ Model represents Return on Assets as dependent variable, brand value as independent variable and include control variables in order to control the effect of such variables on dependent variable.

$I^{\text {st }}$ MODEL ROA $=\alpha+\beta_{1}$ BV $+\beta_{2}$ AGE $+\beta_{3}$ BANK SIZE + $\beta_{4}$ OWNERSHIP $+\mathrm{E}$

$\mathrm{II}^{\text {nd }}$ MODEL ROE $=\alpha+\beta_{1} \mathrm{BV}+\beta_{2}$ AGE $+\beta_{3}$ BANK SIZE + $\beta_{4}$ OWNERSHIP + E

III ${ }^{\text {rd }}$ MODEL ROI $=\alpha+\beta_{1}$ BV $+\beta_{2}$ AGE $+\beta_{3}$ BANK SIZE + $\beta_{4}$ OWNERSHIP + E

$\mathrm{IV}^{\text {th }}$ MODEL Stock Prices $=\alpha+\beta_{1}$ BV $+\beta_{2}$ AGE $+\beta_{3}$ BANK SIZE $+\beta_{4}$ OWNERSHIP + E

$\mathrm{V}^{\text {th }}$ MODEL EPS $=\alpha+\beta_{1}$ BV $+\beta_{2}$ AGE $+\beta_{3}$ BANK SIZE + $\beta_{4}$ OWNERSHIP + E 
Where

$\alpha=\alpha$ is Constant or Intercept

$\beta=\beta$ is the coefficient of each variable.

ROA $=$ Return on Assets

$\mathrm{ROE}=$ Return on Equity

$\mathrm{ROI}=$ Return on Investments

Stock Prices $=$ Stock Prices of the bank

EPS = Earnings per Share of the bank

$\mathrm{BV}=$ Brand value

$\mathrm{AGE}=$ Age of the Bank

BANK SIZE $=$ Size of the bank

OWNERSHIP $=$ ownership (public or private) of the bank

$\mathrm{E}_{=}$representing the Error term

\section{Empirical Results}

The empirical evidences with regard to impact of Brand value on the financial performance of banks are explained in Table 1, 2, 3, 4 and 5. The financial performance of banks is categorized into accounting based measures and market based measures. Accounting based measures are Return on Assets (ROA), Return on Equity (ROE) and Return on Investments (ROI). Market based measures are comprised of Stock Prices and Earning Per share. The data are analyzed using the regression analysis to test the relationships existing between the dependent variable and independent variables. However, Brand value, bank characteristics and Time dummies have been used as explanatory variables. One Time dummy has been omitted for the analysis.

Before applying the regression model, the assumptions of Normality, Multicollinearity and Autocorrelation have been checked. Normality assumption has been checked through Komologorov- Smirnov Test. Age and Firm Size found to be at normal distribution level. As far as Brand value is concerned, test statistics have rejected the assumption of normality. Therefore, the next step is to transform the non-normal variable. However, Brand value has been transformed by taking its logarithm.

Multicollinearity has been tested through VIF (Variance Inflation Factor). The rule of thumb indicated that if VIF of variable is less than 10 , then there is no problem of Multicollinearity with that variable. In the study, VIF of Independent variable and control variables is less than 10 . Hence, the data is free from Multicollinearity problem.

The assumption of autocorrelation has been checked through Durbin Watson (d) statistic value. As per decision rule, if $\mathrm{d}$ is 2 or close to 2 , then there is no first order autocorrelation either positive or negative. In our analysis, data is free from autocorrelation problem also.

\section{Regression Model}

This section summarizes the results of regression model in Table 1. In the first model, the dependent variable is financial performance measured with Return on Assets
(ROA). Table 1 shows the regression of the ordinary least square results conducted on the specified model. The OLS results reveal the relationship that exists between the dependent variable and each of the independent variables. Table 1 shows OLS regression results.

Table 1. Summary of Results

\begin{tabular}{|c|c|c|c|}
\hline Variable & Coefficient & T value & P Value \\
\hline C & 1.644 & 5.58 & $.000^{* * *}$ \\
\hline BV & -.069 & -2.56 & $0.013^{* * *}$ \\
\hline Firm Size & -.249 & -1.57 & 0.120 \\
\hline Age & .181 & 1.76 & $0.083^{*}$ \\
\hline Ownership & -1.02 & -4.30 & $0.000^{* * *}$ \\
\hline
\end{tabular}

$\mathrm{R} 2=0.626, \mathrm{~F}(3=11,68)=10.35$, Prob $>\mathrm{F}=0.000 . * * *$ significant at $1 \%$ level, **significant at $5 \%$ level, *significant at $10 \%$ level

Table 1 exhibits the regression results of impact of brand value on financial performance measured with Return on Assets. F statistics are significant at $1 \%$ level of significance which reveals that the model is significant. Brand value is found to be significantly negatively associated with Return on Asset as $\mathrm{P}$ value $<.05$. This negative relationship reflects that bank investments in brand leads to reduction in its return on assets. Although Brand is regarded as an important asset of the company but it doesn't generate return for the banks because Indian banks are not very much inclined towards optimum utilization of brand investments.

Size has negative but insignificant relationship with Return on Assets. Previous studies on the relationship between size and financial performance provide mixed evidences. Chen (2001), Weir et al (2003), Mollah \& Talukdar (2007) revealed negative relationship between size and financial performance. Larger banks do not necessarily have high financial performance due to certain diseconomies of scale.

Age is found to be positively associated with Return on Assets and it is significant at $10 \%$ level of significance. The results reflect that older banks are more profitable than new ones. One of the probable reason could be older banks have established themselves firmly in the market and also take the benefits of economies of scale which the new banks are difficult to achieve. Chen (2001) stated that older firms are considered as more efficient than the newcomers.

Ownership is found to be negatively associated with Return on Assets and it is significant at $1 \%$ level of significance. It shows that private sector banks have more Return on Assets than public sector banks. Bandyopadhyan (2008) claimed that the ROA of private sector banks have not dropped below 1.09\% since 2004 whereas public sector banks have not been able to achieve $1 \%$ ROA. This proves that private sector banks are performing better as compared to public sector banks. Similar findings were found in the study of Uttarwar (2014) which showed that in the past five years private sector banks have earned significantly higher return on assets as compared to their pubic peers.

In the second model, the dependent variable is financial 
performance measured with Return on Equity (ROE).

The table 2 shows the regression of the ordinary least square results conducted on the specified model. The OLS results reveal the relationship that exists between the Return on Equity and each of the independent variables. Table 2 shows OLS regression results.

Table 2. Summary of Results

\begin{tabular}{|c|c|c|c|}
\hline Variable & Coefficient & T value & P Value \\
\hline C & 29.52 & 6.13 & $0.000^{* * *}$ \\
\hline BV & -0.87 & -1.97 & $0.053^{* *}$ \\
\hline Firm Size & -9.00 & -3.48 & $0.001^{* * *}$ \\
\hline Age & 1.96 & 1.16 & 0.248 \\
\hline Ownership & -7.91 & -2.04 & $0.046^{* *}$ \\
\hline
\end{tabular}

$\mathrm{R} 2=0.2861, \mathrm{~F}(3=11,68)=2.48$, Prob $>\mathrm{F}=0.011 . * * *$ significant at $1 \%$ level, $* *$ significant at $5 \%$ level, *significant at $10 \%$ level

The above table reflected that brand value has significant negative impact on ROE at 5\% level of significance. This negative phenomenon indicates the marginal diminishing returns of the bank's brand advantage; ceteris paribus (Tsai and Chang, 2012).It reveals that bank expenditure on brand initiatives does not increase its return. It negatively influences the return on equity of banks because brand investment is a long term investment and its benefits are reflected in the long run.

Firm size is found to be negatively associated with ROE and it is significant at $1 \%$ level of significance due to diseconomies of scale in the analyzed years. The findings of the study are consonant with the findings of Gherghina et al (2015) which exerts the negative relationship between size and ROE due to diseconomies of scale.

Age is found to have insignificant influence on Return on equity as $\mathrm{p}$ value is more than 0.05 . Mixed evidences are found in the literature regarding the relationship between age and financial performance measured with Return on Equity. Singh (1997), Sheu and Yang (2005) and Kaur (2005) claimed that when firms reaches its maturity stage, age has insignificant impact on financial performance.

Ownership also has negative significant impact on ROE. Private sector banks have more ROE than public sector banks. Kumar (2009) stated that the return on equity of public sector banks is negative. The findings of Bonin, Hasan and Wachtel (2002) are also consonant with the findings of current study.

In the Third model, the dependent variable is financial performance measured with Return on Investments (ROI)

The table 3 shows the regression of the ordinary least square results conducted on the specified model. The results reveal the relationship that exists between the Return on Investments and each of the independent variables. Table 3 shows OLS regression results.
Table 3. Summary of Results

\begin{tabular}{|c|c|c|c|}
\hline Variable & Coefficient & T value & P Value \\
\hline C & 8.44 & 13.70 & $0.000^{* * *}$ \\
\hline BV & -.156 & -2.73 & $0.008^{* * *}$ \\
\hline Firm Size & -4.97 & -1.38 & 0.172 \\
\hline Age & .003 & 1.26 & 0.214 \\
\hline Ownership & -.403 & -0.98 & 0.332 \\
\hline
\end{tabular}

$\mathrm{R} 2=0.45, \mathrm{~F}(3=11,68)=5.07$, Prob $>\mathrm{F}=0.000 . * * *$ significant at $1 \%$ level, $* *$ significant at $5 \%$ level, *significant at $10 \%$ level

The above table reflected that ROI has significant negative impact on brand value at $1 \%$ level of significance. One of the probable reasons for this negative phenomenon is mounting cost pressures, scarce resources and the stress of economic recession. The results are consonance with the findings of Verbeeten and Vijin, 2006 which revealed the negative impact of brand on Return on Investments.

Firm size has negative but insignificant influence on Return on Investments .In other words no significant impact of size on return on investments.

Table 4. Summary of Results

\begin{tabular}{|c|c|c|c|}
\hline Variable & Coefficient & T value & P Value \\
\hline C & -2757.734 & -6.43 & $0.000^{* * *}$ \\
\hline BV & 132.225 & 3.34 & $0.001^{* * *}$ \\
\hline Size & 379.109 & 1.64 & 0.105 \\
\hline Age & 733.699 & 4.88 & $0.000^{* * *}$ \\
\hline Ownership & -1384.261 & -4.00 & $0.000^{* * *}$ \\
\hline
\end{tabular}

$\mathrm{R} 2=0.647, \mathrm{~F}(11,68)=11.36$, Prob $>\mathrm{F}=0.000 . * * *$ significant at $1 \%$ level, **significant at $5 \%$ level, *significant at $10 \%$ level

Age has positive but insignificant influence on Return on Investments. The findings are consonant with Chen (2001), Sheu and Yang (2005) and Kaur (2005) which depicted insignificant influence of age on financial performance. One of the probable reasons could be dependence of older banks to old technologies which resist the banks to improve financial performance.

Ownership has negative but insignificant influence on Return on Investments. It shows that private sector banks have more Return on investments than public sector banks.

In the fourth model, the dependent variable is financial performance measured with Stock Prices The table 4 shows the regression of the ordinary least square results conducted on the specified model. The OLS results reveal the relationship that exists between the stock prices and each of the independent variables. Table 3 shows OLS regression results.

Table 4 exhibits the impact of brand value on financial performance of banks measured with Stock Prices. The results reflected the positive relationship between stock prices and Brand value and this relationship is significant as $\mathrm{P}$ value is less than .05.The results of the study are consistent with the findings of Simon \& Sullivan (1993);Barth et al (1998); Chu \& Keh (2006) ; Ohnemus \& Jenster(2007); 
Mizik \& Jacobson (2008); Edmans (2011); Kirk et al. (2012); Hsu et al (2013).These studies reflected that brand value is the building block which helps in accelerating the share prices. Investors prefer to hold shares in well-known companies and Brand value act as a proxy for assessing the reputation and goodwill of the company, Eng \& Keh (2007). Edmans (2011) also asserted that higher brand value lead to more share prices.

Firm Size is positively associated with Stock prices which reveal that as size of the bank increases, stock prices also increases. The share prices of large sized banks are more as compared to small sized banks. The stock prices of State bank of India are more than the stock prices of Canara bank from 2007 to 2014( Prowess ,2014).

Age is found to be positively associated to stock prices which show that as age of the bank increases, it share prices also increases. The stock prices of older banks are better as compared to new banks.

Ownership is found to be significantly negatively associated with stock prices which revealed that the stock prices of private banks are more than the public sector banks in the analyzed years.

In the fifth model, the dependent variable is financial performance measured with Earnings per share (EPS).

The table 5 shows the regression of the ordinary least square results conducted on the specified model. The OLS results reveal the relationship that exists between the Earnings per share and each of the independent variables. Table 5 shows OLS regression results.

Table 5. Summary of Results

\begin{tabular}{|c|c|c|c|}
\hline Variable & Coefficient & T value & P Value \\
\hline C & -121.342 & -3.65 & $0.001 * * *$ \\
\hline BV & 9.324 & 3.04 & $0.003 * * *$ \\
\hline Size & -27.245 & -1.52 & 0.132 \\
\hline Age & 43.813 & 3.76 & $0.000^{* * *}$ \\
\hline Ownership & -58.47 & -2.18 & $0.033^{* *}$ \\
\hline
\end{tabular}

$\mathrm{R} 2=0.661, \mathrm{~F}(11,68)=12.07$, Prob $>\mathrm{F}=0.000 . * * *$ significant at $1 \%$ level, $* *$ significant at $5 \%$ level, *significant at $10 \%$ level

Table 4 shows the regressions results on the impact of brand value on the financial performance measured with Earnings per Share. The table reflected the positive relationship between Earnings per share and Brand value and this relationship is significant as $\mathrm{P}$ value $<.05$. The results of the study are consistent with the findings of Madikizela (2007); Angulo (2007); Jacob and Mizik (2009) and hold the view that a high brand value increases the reputation and image of the bank in the market which persuade the new investors to buy shares and raises the earnings attached with the shares of banks.

No significant association is found between size and financial performance measured by Earnings per Share.

Age is found to be positively related to Earnings per Share and this relationship is significant at $1 \%$ level of significance. The results reflected that older banks are established and mature. They have gained reputation and goodwill in the market which ultimately increase their share prices as well as Earnings per share.

Ownership is negatively associated with EPS and it is significant at $5 \%$ level of significance. Negative associations reveal that private sector banks have better Earnings per share as compared to public sector banks because the share prices of private sector banks are better in the crisis period.

\section{Conclusions}

The findings of the study establishes a strong relationship between brand value and ROA, ROE, Stock Prices and EPS which revealed significant impact of brand value on the financial performance of banks. It is evident that ROA, ROI and Stock Prices emerged as the strong predictors of Brand value. ROA, ROI and Stock Prices are significant at $1 \%$ level of significance .ROE and EPS is significant at 5\% level of significance as $p$ value is less than 0.05 . The study revealed negative influence of brand value on ROA, ROE and ROI which shows that excessive advertising and media prominence leads to increase in the brand value of banks but decreases its return. So the banks need to keep an eye on their brand investments because excessive expenditure on brand leads to decrease in the return on equity (Hynes, 2008). This negative relationship reveals that bank investments in brand leads to reduction in its return on assets, return on equity and return on investments. In order to survive in the market, banks tried to improve the market position by investing in brand initiatives which is the root cause of negative return in the study. Whereas, this negative phenomenon indicates the marginal diminishing returns of the bank's brand advantage and excessive cost due to increased expenditure on brand initiatives. Consistent with the previous findings i.e. Hynes (2008), Ohnemus (2010) \& Tsai and Chang (2012), banks with brand advantage subsequently have a lower Return on assets, Return on Equity and Return on Investments because more investments in brand initiatives leads to reduction in its return. So there should be proper check on the investment done in accelerating brand initiatives. The findings of the study also revealed that Ownership is negatively associated with Return on Assets, Return on Equity and Return on Investments. The main reason behind this trend is the negative influence of subprime crisis on Public sector banks. Sharma \& Panwar, 2014 revealed that during crisis period, the performance of private sector banks was much more stable than public sector banks. Size of the bank is negatively associated with ROA, ROE and ROI which reflected larger banks do not necessarily have high financial performance. These banks might face certain diseconomies which negatively affect their performance. Age of the bank has positive influence on financial performance which reflects that the performance of banks can be improved with the passage of time. Therefore, the results of the study strongly recommend that investments in brand affect the financial performance of banks. 
The study also revealed the positive relationship between Stock prices and Brand value and this relationship is significant at $1 \%$ level of significance .The results of the study are consistent with the findings of Simon \& Sullivan (1993);Barth et al (1998); Chu \& Keh (2006) ; Ohnemus \& Jenster(2007); Mizik \& Jacobson (2008); Edmans (2011); Kirk et al. (2012); Hsu et al (2013).These studies reflected that brand value is the building block which helps in accelerating the share prices. Investors prefer to hold shares in well-known companies and Brand value act as a proxy for assessing the reputation and goodwill of the company (Eng \& Keh, 2007). Edmans (2011) also asserted that higher brand value lead to more share prices. The study also reflected the positive and significant relationship between Earnings per share and Brand value. This positive relationship depicts that a high brand value increases the reputation and image of the bank in the market which helps them to achieve higher earnings. The results of the study are consistent with the findings of Madikizela (2007); Angulo (2007); and Mizik (2009). Moreover, Bank Size has insignificant influence on stock prices and EPS. Age is found to be positively associated to stock prices as well as EPS which show that as age of the bank increases, it share prices and Earnings per share also increases. Ownership is found to be significantly negatively associated with stock prices which revealed that the stock prices of private banks are more than the public sector banks in the analyzed years. As revealed from the study, a high brand value doesn't lead to increase in accounting performance of banks measured with ROA, ROE and ROI but significantly improve the market performance of banks measured with Stock prices. Therefore, banks should be more concerned about optimum utilization of brand investments and try to reduce their costs effectively. This is important for enhancing their return and providing benefits to equity shareholders. In the nutshell, Brand value has positive influence on market performance of banks because brand is a marketing asset and all the branding initiatives taken by bank will result in improved market position whereas it has negative influence on accounting performance of banks because expenditure on brand reduces the revenue of the banks which will further affect the accounting performance of banks.

\section{REFERENCES}

[1] Aaker, David A. (1991). "What Is Brand Equity? Managing Brand Equity: Capitalizing on the Value of a Brand Name". New York, NY: The Free Press,1-33.

[2] Aaker, D. A., and R. Jacobson. 1994. "The Financial Information Content of Perceived Quality." Journal of Marketing Research. 31: 191-201.

[3] Aaker, D. A. (1996). "Building Strong Brands". New York: The Free Press.

[4] Aaker, D. A., and R. Jacobson. 2001. "The Value Relevance of Brand Attitude in High-Technology Markets.' Journal of Marketing Research.38: 485-493.

[5] Angulo L.F. (2007). "The Interplay between Cumulative Customer Satisfaction and Brand Value: Its Effect On Cash Flow, Roi And Tobin's Q". PhD Thesis. Department D'economia De L'empresa, Universitat Autonoma De Barcelona.

[6] Capraro J. \& Srivastava R.K.(1997). "How Do Reputations Affect Corporate Performance? Has The Influence Of Financial Performance On Reputation Measures Been Overstated?" Corporate Reputation Review. 1(1):86-92.

[7] Chakraborty S. (2013). "Brand Value: Smaller Banks take big steps". Retrieved from www.business standard.com.

[8] Doyle P. (2001). "Shareholder-Value-Based Brand Strategies, Brand Management". 9(1): 20-30.

[9] Eng, L. L., \& H. T. Keh. 2007. "The Effects of Advertising and Brand Value on Future Operating and Market Performance.' Journal of Advertising.36: 91-100.

[10] Farquhar, P.H. (1989). "Managing brand equity”. Marketing Research.12:321-32.

[11] Farquhar, P.H. (1994). "Strategic challenges for branding". Marketing Management, 3(2): 8-15.

[12] Hynes A. (2008). "Media Prominence: A Leading Indicator of Brand Value". Retrieved from www.bynd.com

[13] Kim H.B., W. G. Kim W.G. \& An J.A. (2003). "The Effect Of Consumer-Based Brand Equity on Firm's Financial Performance". Journal of Consumer Marketing. 20(4):335-351.

[14] Kerin R. A. and Sethuraman R. (1998). Exploring the Brand Value-Shareholder Value Nexus for Consumer Goods Companies. Journal of the Academy of Marketing Science, 26: $260-273$.

[15] Kallapur S. \& Kwan S. Y. (2004). "The Value Relevance and Reliability of Brand Assets recognized By U.K. Firms". Accounting Review, 79(1):151-172.

[16] Keller, K. L., and D. R. Lehmann (2006). "Brand and Branding: Research Findings and Future Priorities." Marketing Science .25: 740-759.

[17] Lane V. \& Jacobson R. (1995). "Stock Market Reactions To Brand Extension Announcements: The Effects Of Brand Attitude And Familiarity". The Journal Of Marketing.56:63-77.

[18] Lopo L. Rego, Matthew T. Billett, \& Neil A. Morga (2009). "Consumer-Based Brand Equity and Firm Risk". Journal of Marketing. 73:47-60.

[19] Madden T.J., Fehle F. \& Fournier S. (2002). "Brands Matter: An Empirical Demonstration of the Creation of Shareholder Value through Branding". Journal of the Academy of Marketing Science. 34(2): 224-235.

[20] Madikizela (2007). "Evaluation of the Impact of Brand Equity on Shareholder Returns amongst South African Companies". Master Thesis. Gordon Institute of Business Science, University Of Pretoria.

[21] Neff J. (2011). Unraveling the Mystery of How Brand equity 
affects sales, profit. Retrieved from http://adage.com/article/ news/wpp-panel-aims-learn-brand-equity-affects-sales

[22] Ohnemus (2009), Brand Thrust: Strategic Branding and Shareholder Value, $\mathrm{PhD}$ Thesis, the $\mathrm{PhD}$ School of Economics and Management, Copenhagen Business School, Denmark.

[23] Rasti P. \& Gharibvand S. (2013). The Influence of Brand Value on Selected Malaysian's Companies Book Value and Shareholders. Review of Contemporary Business Research. 2 (1).12-19.

[24] Simon C.J. \& Sullivan, M. W. (1993). "The measurement and determinants of brand equity. A financial approach". Marketing science. 12(1):28-52.

[25] Smith, R. E., and W. F. Wright. 2004. "Determinants of Customer Loyalty and Financial Performance.' Journal of Management Accounting Research. 16: 183-205.

[26] Sinclair (2009), The Importance of Brand Equity in Creating
Firm Value. White paper. Retrieved from www.Prophet.Com

[27] Stahl F., Heimann M., Lehman D.R. \& Neslin S.A. (2012). The impact of customer acquisition, retention and profit margin. Journal of Marketing. 76(4): 44 -63

[28] Tsai J. Y \& Chang C. P. (2012). Call-pricing equity returns and default risks of entry mode with brand perception in retail banking. International Review of Economics and Finance .21 . $29-41$

[29] Verbeeten \& Vijin (2006). "Are Brand-Equity Measures Associated With Business-Unit Financial Performance? Empirical Evidence from the Netherlands". Journal of Accounting, Auditing \& Finance, 25 (4):645-671.

[30] Verbeeten and Vijin (2006). "Do Strong Brands Pay Off? An Empirical Investigation Of The Relation Between Brand Asset TM Valuator And Financial Performance ".NRG Working Paper Series, January 2006 (Nyenrode Research Group) Working Paper No. 06-03 